\title{
Correction to: Perinatal Sexual Dysfunction: the Importance of the Interpersonal Context
}

\author{
Erin T. Fitzpatrick ${ }^{1}$ - Marta T. Kolbuszewska ${ }^{1}$ Samantha J. Dawson ${ }^{1,2}$
}

Published online: 4 September 2021

(c) Springer Science+Business Media, LLC, part of Springer Nature 2021

The original article can be found online at https://doi.org/10.1007/ s11930-021-00313-8.

Samantha J. Dawson

sdawson@psych.ubc.ca

1 Department of Psychology, University of British Columbia, Vancouver, Canada

2 Department of Psychology, University of British Columbia, 2136 West Mall, Vancouver, Canada 


\section{Correction to: Current Sexual Health Reports}

https://doi.org/10.1007/s11930-021-00313-8

The original article unfortunately was published with an error. We misdescribed the sample and thus the findings of one paper in an important way.

The original article has been corrected.
Publisher's Note Springer Nature remains neutral with regard to jurisdictional claims in published maps and institutional affiliations. 